\title{
An Approach of Travel Time of Flood Peaks and Runoff Model towards Low Impact Development
}

\author{
$R$ I Siregar, N Nursyamsi, I Indrawan, $R$ A Sembiring, $R$ Karolina, and \\ $R$ A Dewi
}

Civil Engineering Department, Faculty of Engineering, Universitas Sumatera Utara, Kampus USU, Padang Bulan, Medan 20155, Indonesia

\begin{abstract}
The most crucial point for the planning of the city should be considered flooding conditions. In manipulating the length of the channel, of course also manages the direction of the stream, so that the size of the catchment area in the area will be different. The characteristics of surface runoff of urban drainage systems are essential to determine the effects of runoff reduction towards Low Impact Development (LID). In this study, to make modelling of stormwater runoff characteristics in a city can be analysed by using the Stormwater Management Model (SWMM). This research is to explain the method of approaching travel time of flood peaks and runoff in a drainage network system that needs a rainfall-runoff model, EPA SWMM model that shown flood peak in the return period 5-yr and 10-yr, and need representatives to the graph of travel time and runoff. The result shows that the channel only accommodates return period of flood 5-yr, not the 10-yr. The drainage network system consists of minor drainage and major drainage (river) that can be simulated to reduce the runoff. The approach influenced by the direction of flow and the roughness. These parameters are the vital point to manage the travel time of peak floods. The, by redesign and update the capacity of the channel can reduce the overflow over the nodes (junctions).
\end{abstract}

Keyword: Flood, LID, Modelling, Runoff, SWMM, Travel time

\begin{abstract}
Abstrak. Titik paling penting untuk perencanaan kota harus dipertimbangkan kondisi banjir. Dalam memanipulasi panjang saluran, tentu saja juga mengatur arah aliran, sehingga ukuran daerah tangkapan di daerah tersebut akan berbeda. Karakteristik limpasan permukaan sistem drainase perkotaan sangat penting untuk menentukan efek pengurangan limpasan terhadap Pembangunan Berdampak Rendah (LID). Dalam penelitian ini, untuk membuat pemodelan karakteristik limpasan stormwater di suatu kota dapat dianalisis dengan menggunakan Stormwater Management Model (SWMM). Penelitian ini adalah untuk menjelaskan metode pendekatan waktu tempuh dari puncak banjir dan limpasan dalam sistem jaringan drainase yang membutuhkan model curah hujan-limpasan, model EPA SWMM yang menunjukkan puncak banjir pada periode kembali 5-tahun dan 10-tahun, dan kebutuhan mewakili grafik waktu perjalanan dan limpasan. Hasilnya menunjukkan bahwa saluran hanya mengakomodasi periode ulang banjir 5-tahun, bukan 10-tahun. Sistem jaringan drainase terdiri dari drainase minor dan drainase besar (sungai) yang dapat disimulasikan untuk mengurangi limpasan.
\end{abstract}

Kata Kunci: Banjir, LID, Pemodelan, Runoff, SWMM, Waktu Tempuh

Received 23 October 2019 | Revised 26 February 2020 | Accepted 27 February 2020

*Corresponding author at: Faculty of Engineering, Kampus USU, Padang Bulan, Medan 20155, Indonesia 


\section{Introduction}

Flood mitigation during the rainy season, and determining critical urban water catchment subareas is essential for urban planners, where we have to pay attention to the situation making the possibility of a flood. The probability of water levels exceeding baseline conditions is determined for the simulation period [1]. The most important point for the planning of the city should be considered flooding conditions, particularly considering the benefits of keeping rivers as the mayor drainage and their floodplains in managing flood peaks [2]. Because of the lack of information, analysing with a simulation approach is one practical way to identify flow encounters that get overloaded. Especially developing urban areas equipped with drainage systems, in making urban flood simulations, it is essential to describe the dynamic flow from rainfall to runoff to the outlet discharge [3]. A study analysing rainfall-runoff to model the length of the flow alteration from rainfall to runoff discharge becomes a basis for estimating the course of flood peaks [4]. It is known that in predicting floods impacts arising from land-use change and increasing rainfall intensity, within the condition of existing drainage channels and river capacity that remain similar to the original design. One of the alternatives that can be conducted is to use the approach method to analyse the travel time from the amount of runoff that flows through minor drainage and major drainage. The time of concentration on minor drainage is influenced by the length of the channel, slopes, and the roughness of the channel. The relationship between the travel time of the peak flood and the amount of runoff is to set the travel time will certainly affect the number of flood flow. When manipulating the length of the channel, of course also manages the direction of the stream, so that the size of the catchment area in the area will be different [5]. This research is an attempt towards the concept of Low Impact Development (LID). Low Impact Development is an alternative approach in the management of stormwater runoff impacts [6]. An approach study that has been implemented in a case study such a campus analyse peak discharge simulation between the current situation and by implemented Low Impact Development (LID) can reduce until 95\% of runoff. The LID implementation, such as green roof, using the permeable pavement, waterway management, and others [7]. The research purpose is to analyse the method of approaching travel time of flood peaks and runoff in a drainage network system. The drainage network system consists of minor drainage and major drainage (river). This research will also lead to an urban drainage management system approach to reducing the effects of stormwater. It is hoped that the concept can be implied towards a zero runoff concept to become a flood-free city. To achieve this goal, the following detailed objectives, first, analysis of travel time of flood peaks and runoff for urban flood control. Second, based on the Ministry of Public Works regulations for the study of drainage network system planning, modelling of flood discharge rates for 5-year return periods, which means the probability of occurrence of discharge or rain of $20 \%$ will be exceeded once in 5 years, and also modelling flooding of return periods and 10-year. Third, after modelling, 
identify locations that have peak flow loads (at the intersection and discharge outlet). Fourth, the simulation of flood control is based on the regulation of travel time and runoff flow load.

\subsection{Urban Drainage Systems}

The urban drainage planning system is planning for a way to collect runoff from a settlement, road surface which is forwarded to the disposal outlet, a river, lake or sea. The purpose of the management of rainwater falling into the surface runoff is flood and pollution mitigation without much focus on the hydrological changes that occur [8]. The research identified an area that improved urban flood management that emphasised the concept of flood vulnerability and the concept of dealing with increased stormwater runoff capacity and improving the function and quality of the urban environment. Urban water management systems need to consider integrated elements in a multifunctional urban environment [9]. Based on research by Zhu et al., 2016, it was stated that the increase in runoff would result in inundation of urban flooding, as a severe challenge indicated from urban catchment areas [10].

\subsection{Low Impact Development (LID) Concept}

The point concept is by increasing precipitation infiltration, storage of water, and reducing runoff. These technologies are essential tools for future urban construction towards Low Impact Development (LID) [11]. Low-impact development (LID) is an essential approach to stormwater mitigation. Modelling the effects of these installations using rainfall-runoff simulations can provide useful data for future design and implementation [12]. The increasing of stormwater and runoff cause problem such as flooding, where it can be prevented by developing the development of green cities that implemented Low Impact Development (LID) [13].

\subsection{State of The Art}

Previous research serves to analyse and enrich research discussions, as well as differentiate them from the research being carried out of this research. The critical point towards Low Impact Development is how to reduce stormwater by analysing the elements of floods.

Table 1. The Previous Research toward Reducing Runoff

\begin{tabular}{cll}
\hline No. & \multicolumn{1}{c}{ Title } & \multicolumn{1}{c}{ Review result } \\
\hline 1 & $\begin{array}{l}\text { Estimation of the relationship } \\
\text { between the travel time of flood } \\
\text { peaks and peak discharge on the } \\
\text { Poprad River by Multilinier } \\
\text { Flood Routing [4] }\end{array}$ & $\begin{array}{l}\text { This study analyses the empirical relationship between travel } \\
\text { time and flood discharge by modelling the time parameter } \\
\text { variability. The study results reveal that by analysing the } \\
\text { variability of travel time can improve accuracy in predicting the } \\
\text { spread of flooding. }\end{array}$ \\
\hline $2 \quad \begin{array}{l}\text { Modelling stormwater } \\
\text { management at the city district } \\
\text { level in response to changes in } \\
\text { land use and low impact } \\
\text { development [14] }\end{array}$ & $\begin{array}{l}\text { This study aims to analyse the stormwater runoff response to } \\
\text { land-use change conversion with some scenarios using SWMM } \\
\text { and GIS. The results obtained that complex topography and a } \\
\text { large number of sub-watersheds in urban areas ideally require } \\
\text { input parameters for SWMM should be obtained through direct } \\
\text { field surveys and observations. }\end{array}$ \\
\hline
\end{tabular}


3 How does imperviousness impact the urban rainfall-runoff process under various storm cases? [15]
This study aims to model the catchment area in the drainage system with the rainfall-runoff model. Three runoff parameters: Qt, Qp, and time lag (tg) using the SWMM model. The study results that an inaccessible area that is directly connected is essential travel time.
4 Effect of inlet modelling on surface drainage in coupled urban flood simulation [3]
This study aims to model the rainfall-runoff process in estimating excess runoff entering the sewer system through the inlet to route water flow. The results showed that inlet modelling has a strong influence on drainage efficiency in flood simulations.
5 Influence of land development on stormwater runoff from mixed land use and land cover catchment [16]
This study determines the effect of the development of land use is analysed in reducing the impact of stormwater runoff. The results show that the expansion of deforested land and impervious cover, land-use changes and high amounts of rainfall affect the variability of rainwater runoff during various phases of land development.

Based on the previous research, the reducing peak floods as the runoff when high rainfall intensity, is the key to the Low Impact Development. Land-use and travel time management can be conducted to reduce storm-water. A research study shows the change of flow coefficient from 0,65 to 0,69 can occur the changes in inundation area are almost ten per cent greater [17]. In this research, as the state of the art is to analyse the runoff and travel time by paid attention to the integrated minor drainage and major drainage.

\section{Method and Data}

\subsection{Study Area and Urban Land Use Types}

The study area in this modelling is the study location as an example model to help how to analyse in integrating minor drainage and major drainage. The study location is in the drainage system of the Universitas Sumatera Utara, Medan, Indonesia, the campus that towards ecogreen campus (as minor drainage), which has 3 (three) outlets leading to the Babura River (as major drainage), where there is a meeting point between Babura River and Bekala River before the outlet of drainage. On the outlet of drainage. The drainage system at the Universitas Sumatera Utara is also equipped with several automatic floodgates. The campus environment, which has sufficient green open land, will certainly reduce flooding [18]. However, if the flow conditions from the campus are unable to flow to the major drainage, it will undoubtedly be a problem. The definition of minor urban drainage is a network of drainage systems that serve such as residential areas, commercial areas, offices, and industrial estates, markets and tourist areas. The definition of major urban drainage is a network system drainage structurally composed of the primary channels that accommodate the flow of secondary channels. Secondary channels to provide the flow of the tertiary channels. Tertiary channels to 
accommodate the overflow, respectively. Local drainage networks can directly stream flow channel to the primary, secondary and tertiary.

\subsection{Data Collecting}

Data collection consists of primary data and secondary data: Primary data obtained from field surveys consist of data: direction of drainage flow, outlet/disposal position, base slope of drainage channel, coverage/land use, channel shape, channel wall roughness, width and type of road, cross-section of Babura River, flow velocity Babura River. Secondary data, namely: maximum daily rainfall data for data from at least the last 10 years (2009-2018 from January to December) obtained from Deli Serdang /Sampali BMKG offices for three rainfall measurement stations, Deli Serdang, Tuntungan, and Helvetia; in addition, daily rainfall data for the last 3 months for validation of discharge in the drainage channels and the Babura River. The field survey aims to obtain primary data completeness. The survey guidelines, among others, follow SNI 8066: 2015 on "Procedures for Measurement of River Discharge and Open Channels." Field surveys include Flow direction survey: surveyors record the direction of flow, slope, the shape of the channel, roughness, width and type of road to be added in calculating the catchment area, river cross-section (A) and velocity measurement (V), and survey drainage channels when it rains (for some rain values) for validation purposes.

\subsection{Modelling and Simulations}

The characteristics of surface runoff of urban drainage systems are essential to determine the effects of runoff reduction towards Low Impact Development (LID) [19]. In this study, to make modelling of stormwater runoff characteristics in a city can be analysed by using the Stormwater Management Model (SWMM) [14, 20]. Storm Water Management Model (SWMM) is a free software used to simulate rainfall-runoff models at certain events to get the quality and quantity of surface runoff in urban areas. SWMM is produced by the Water Supply and Water Resources Division of the U.S. The EPA National Risk Management Research Laboratory. Models carried out include: describe the catchment area, drainage network analysis to integrate channel. The Storm Water Management Model (SWMM) is utilised rainfall-runoff modelling software which has LID controls that capable in modelling urban drainage systems [21]. Stormwater management, by some information such as hydrological modelling, hydrological data analysis, and vulnerability assessment, is to stimulate storm scenarios and the urban flooding [22]. The concept of dynamic wave routing analysis, flow tracking analysis that can take account of storage in the channel and backwater effects. The model is for the condition of flood discharge return period on the 5-yr and 10-yr. Each region varies depending on the typology of the city. There are several ways to reach the purpose of this study [23]. Modelling of the Babura River flood. Analysis of the Babura River flood discharge (the primary channel as a discharge from the case study site) is adjusted to the simulation on the return period 5-yr and 
10-yr of floods; Hydrology modeling with the Synthetic Unit Hydrograph Method of SCS Method; Identify the condition of the case study area for the following factors: The meeting points of the nodes that indicating peak loads (at the channel junction joints and outlet discharge outlets); channel capacity; travel time.

\section{$2.4 \quad$ Validation Method}

In the method of validation of hydrological simulation, the optimised parameter sometimes does not give an excellent accuracy performance. One way that can simulate most rainfall events and gives high precision is Nash-Sutcliffe efficiency (NSE) [24]. The process compares the observed discharge and then analysed the parameters that influence the modelling results. Optimum parameter values in calibration found by statistical measures. The result of comparison later determined the strength in predicting the modelling by the Nash-Sutcliffe model of efficiency coefficient (E). The Nash-Sutcliffe Efficiency (NSE) is the two criteria most widely used for calibration and evaluation of hydrological models with observed data [25].

\section{$3 \quad$ Results and Discussions}

\subsection{Major Drainage Hydrograph Model}

In this paper identify how to integrate major drainage and minor drainage to lead to low impact development, namely the river as a major drainage or outlet drainage, and the urban drainage system as minor drainage. Measurements of river discharge and drainage discharge have been carried out, and the following is the Babura River flood hydrograph as USU's major drainage. The following hydrograph is the flood discharge at coordinates 3033 '17,528 "North Latitude and 980 39" 45,716 "East Longitude.
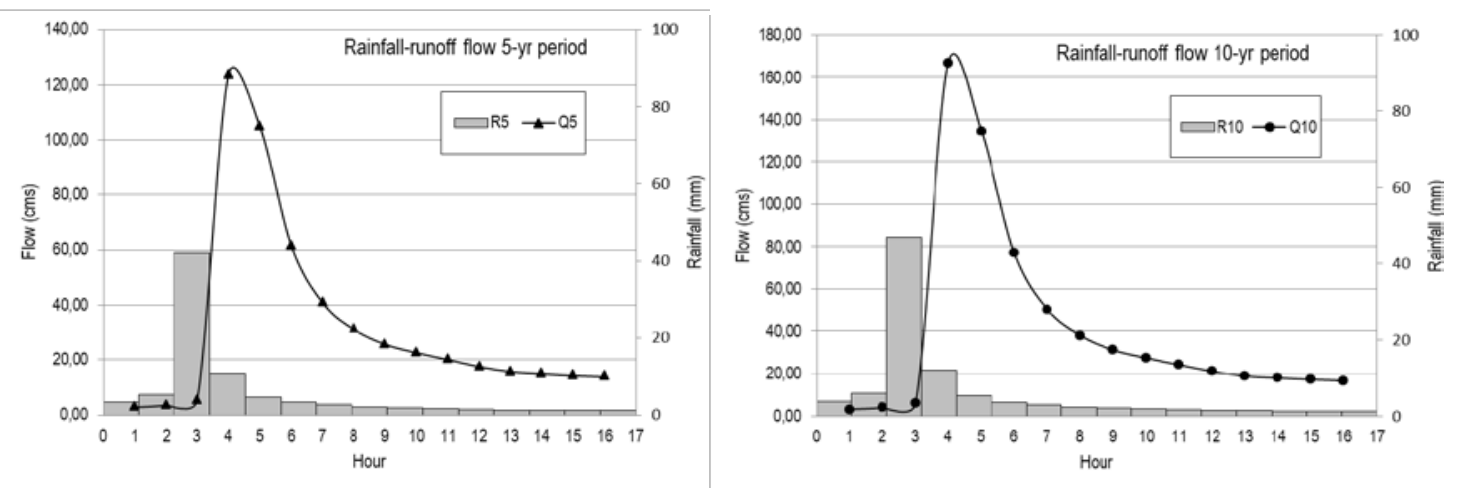

Figure 1. Flood Hydrograph of Babura Bekala Watershed Return Period 5-yr and 10-yr

The graph above shows that the maximum flow of Babura Bekala watershed in 5-yr return period is $123,5 \mathrm{~m}^{3} / \mathrm{s}$, and 10-yr is 166,6 $\mathrm{m}^{3} / \mathrm{s}$. The figure also shows that the Babura Bekala watershed as a drainage outlet, based on the results of hydrological modelling using the SCS method, reaches a maximum discharge at the fourth hour after raining for 3 hours. Based on 
calculations from the Babura River cross-section survey data, it has a full discharge capacity, $170 \mathrm{~m}^{3} / \mathrm{s}$. It is calculated based on the USU drainage outlet point. Due to limited access, measurements were made at 50 meters from the outlet point.

The modelling has been validated for two measurements on rain events on a specific date and made tuning of the synthetic unit hydrograph parameters. The following are the results of Babura Bekala hydrograph validation. The Nash Index of this hydrograph validation is shown below.

Table 2. Study Area and Land Use in Medan

\begin{tabular}{|c|c|c|c|c|c|c|c|}
\hline \multicolumn{4}{|c|}{ Validation 1} & \multicolumn{4}{|c|}{ Validation 2} \\
\hline hour & Q observed & $\begin{array}{c}\mathrm{Q} \\
\text { model }\end{array}$ & $(\mathrm{Qo}-\mathrm{Qm})^{\wedge} 2$ & hour & $\begin{array}{c}\mathrm{Q} \\
\text { observed }\end{array}$ & $\begin{array}{c}\mathrm{Q} \\
\text { model }\end{array}$ & $(\mathrm{Qo}-\mathrm{Qm})^{\wedge} 2$ \\
\hline 4 & 7,060 & 7,4 & 0,116 & 4 & 9,430 & 9,2 & 0,053 \\
\hline \multicolumn{2}{|r|}{$\mathrm{NSE}=$} & & 0,88 & & NSE $=$ & & 0,95 \\
\hline
\end{tabular}

The tables show that in the peak hours of flow, in two validations process, between observed data and the result from the model give a significant index indicating the elements we have tunning are almost reach the real value, the first validation within NSE 0,88 and the second within NSE 0,95.

\subsection{Minor Drainage Model}

The modelling of minor drainage is based on the Stormwater Management Model (SWMM). The drainage model can analyse the spatial variability of catchment properties by dividing the catchment into sub-catchments. First of all, we have to make nodes as the outlet of every conduit and connect them each other based on the flow stream that got from field survey. Then, filling the data of the nodes and channels, and making specifically sub-catchments for every conduit. The picture below is SWMM drainage model on the area of study.

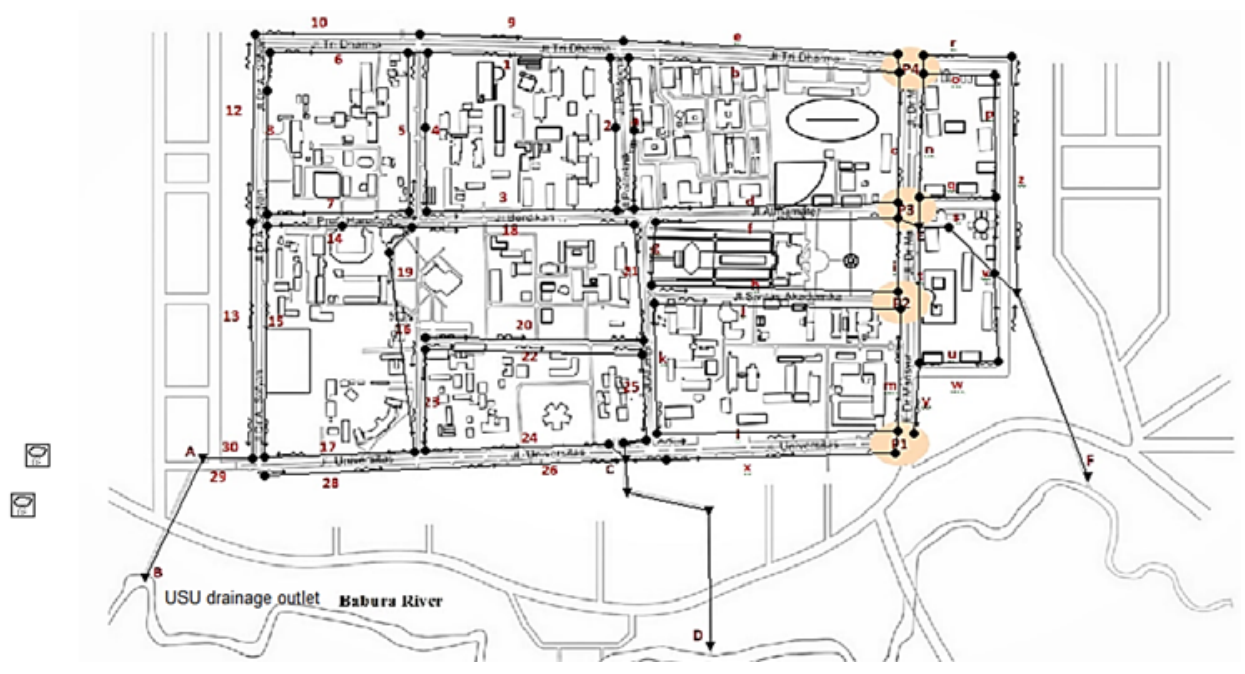

Figure 2. Mayor Drainage and Minor Drainage System by SWMM Model 
The modelling has been validated for two measurements on rain events on a specific date and made tunning of parameters such as roughness and impervious of sub-catchments. The other parameters are based on the field survey such as width and height of conduits, slope and elevation, material type of channels, and maximum depth. The roughness was collected by interpreted the table of roughness, based on the lining type of channels. The following are the results of USU Drainage validation.

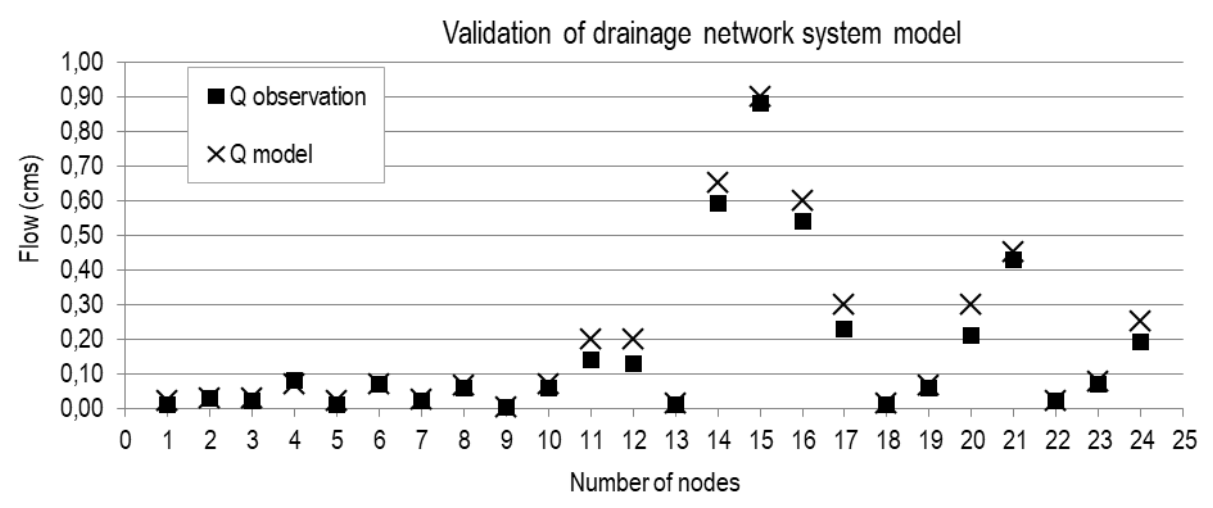

Figure 3. Validation of The Drainage Network System Model

The picture above is the validation of the drainage model that is compered observation flow data and the model result in the number of nodes. It can be seen that many observation flows that got from the field survey are similar to model flow. The Nash-Sutcliffe efficiency (NSE) is 0,97. It means the model almost identical to the observation data based on field survey.

\subsection{Integrated of Major and Minor Drainage}

Babura river has bank-full capacity is about $170 \mathrm{~m}^{3} / \mathrm{s}$, where flood discharge of Babura and Bekala watershed within the return period of 5-yr and 10-yr are 123,5 m/s, and 166,6 $\mathrm{m}^{3} / \mathrm{s}$ respectively. In the return period of 5-yr, the Babura river remains capacity is about $46,5 \mathrm{~m}^{3} / \mathrm{s}$, and it means there is no flooding condition where the rainfall return period of 5-yr. However, it is known that the channel as an outlet for the usu river to Babura River has a maximum capacity of $74.7 \mathrm{~m}^{3} / \mathrm{s}$ in full condition. The channel not only accommodates the drainage flow from USU drainage, but the channel receives the stream from other drainages so that the channel is full capacity, the Babura River is unable to accommodate a total discharge of 198,2 $\mathrm{m}^{3} / \mathrm{s}$. Likewise, the flood conditions for 10-yr return period discharge with the flow of 241,3 $\mathrm{m}^{3} / \mathrm{s}$ originating from the combined river flood discharge and drainage outlet drainage. This condition is a prediction of the flow at maximum conditions (full capacity) at the same amount of rainfall and travel time. Based on the condition of total discharge and discharge capacity, this will certainly cause the area around the study area to receive the impact of flooding caused by the overflowing of the Babura River. Some research on river overflows and as an alternative measure is to make river embankments along the Babura River to increase the capacity of the river and prevent 
water overflows. In the analysis, it is known that the peak flood discharge period of 5-yr and 10yr return period is one hour after the rainfall occurs. Therefore this will not happen when the flow from the USU drainage outlet has a travel time of under one hour or occurs after three hours after rainfall. Due to data limitations, this analysis does not yet involve time to flow from other drainages.

\subsection{Simulation of The Relationship Between Travel Time and Flood Peak Runoff}

The simulations are for the return period of 5-yr and 10-yr. At this stage of the simulation, several things that will be the focus for include: 1) comparing the results of the EPA SWMM model for 5-yr and 10-yr return discharge periods to its drainage channel capacity. It is done to analyse whether the existing channel is still able to accommodate the flood discharge. 2) Then, investigate the ratio of 5-yr and 10-yr return period flood discharges to their capacity discharge at each channel section meeting. The purpose is to find out if there is an overflow in the channel segment meeting, then compared the time the flow travels from node to node. If when the condition of that travel time of flood peak occurs overflow channel so that the setting of flow direction set and the management of runoff reduce are needed. The relationship between travel time of flow of the conduits and the flood peaks is shown below.

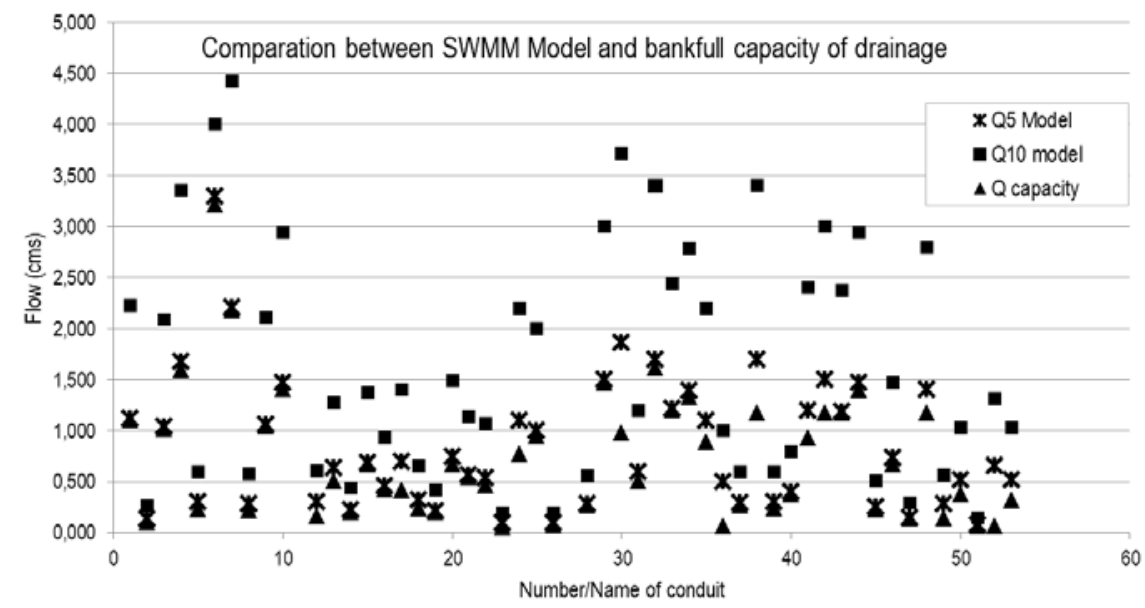

Figure 4. Comparation Between SWMM Model and Bank-Full Capacity of Drainage 


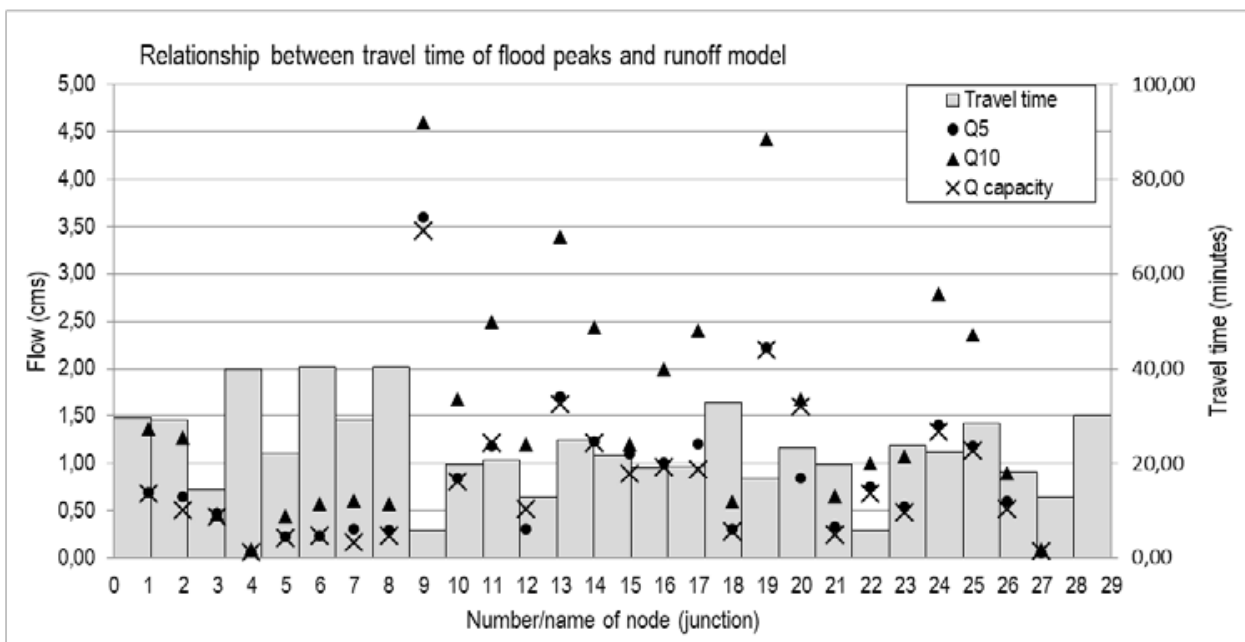

Figure 5. Relationship Between Travel Time of Flood Peaks and Runoff Model

The graph in Figure 4 shows that the drainage channel is still capable in accommodating the peak floods in the return period of 5-yr, but when the return period 10-yr of flood happen, it overload flow than the capacity of drainage on the number of nodes. It means some of the conduits must be improved to prevent the overflow. Figure 5 shows that the nodes (junctions) still can accommodate the flood flow in the return period of 5-yr, but can not do that in the 10-yr of floods. It can be seen from the graph the travel time of flood peaks are not similar to each other, within the average time is 23 minutes. It means the flow reaches the same nodes (junction) have different time. It would be better for the water which flows through the channel.

\section{Conclusions}

This research is to analyse the method of approaching travel time of flood peaks and runoff in a drainage network system that needs a rainfall-runoff model, EPA SWMM model that shown flood peak in the return period 5-yr and 10-yr, and need representatives to the graph of travel time and runoff. The result show that the channel only accommodates return period of flood 5yr, not the 10-yr. The drainage network system consists of minor drainage and major drainage (river) that can be simulated to reduce the runoff. The approach influenced by the direction of flow and the roughness. These parameters are the important point to manage the travel time of peak floods. The, by redesign and update the capacity of the channel can reduce the overflow over the nodes (junctions).

\section{Acknowledgement}

The author gratefully acknowledged that the research was supported by Universitas Sumatera Utara based on USU Talenta Research Implementation Contract, April 2019, with the contract number: 4167/UN5.1.R/PPM/ 2019. 


\section{REFERENCES}

[1] R. I. Siregar, Eds., IOP Conference Series: Material Science and Engineering, September 7-8, 2017, Medan, Indonesia, IOP Publishing, 2018.

[2] W. Su, "Urban Land Pattern Impacts on Floods in a New District of China," Sustainability, vol. 6, pp. 6488-6508, September 2014.

[3] J. H. Jang, T. H. Chang, W. B. Chen, "Effect of inlet modelling on surface drainage in coupled urban flood simulation,” Journal of Hydrology, vol. 562, pp. 168-180, July 2018.

[4] M. Danacova, J. Szolgay, R. Vyleta, "Estimation of The Relationship Between The Travel Time of Flood Peaks and Peak Discharge on The Poprad River by Multilinear Flood Routing,” International Journal of New Technology and Research (IJNTR), vol. 1, pp. 35-39, October 2015.

[5] Storm Water Management Model (SWMM) version 5.1 User's Manual

[6] N. Chang, J. Lu, T. F. M. Chui, N. Hartshorn, "Global policy analysis of low impact development for stormwater management in urban regions," Land Use Policy, vol. 70, pp. 368-383, January 2018.

[7] C. Matos, A. Briga Sa, I. Bentes, S. Pereira, R. Bento, "An approach to the implementation of Low Impact Development measures towards an EcoCampus classification,” Journal of Environmental Management, vol. 232, pp. 654-659, November 2018.

[8] C. J. Walsh et al., "Principles for urban stormwater management to protect stream ecosystems,” Freshwater Science, vol. 35, pp. 398-411, Agustus 2015.

[9] J. Sorensen et al., "Re-Thinking Urban Flood Management-Time for a Regime Shift," Water, vol. 8, no. 332, August 2016.

[10] Z. Zhu, Z. Chen, X. Chen, P. He, "Approach for evaluating inundation risks in urban drainage systems,” Science of the Total Environment, vol. 553, pp. 1-12, May 2016.

[11] J. Zhang, R. C. Peralta, "Estimating infiltration increase and runoff reduction due to green infrastructure," Journal of Water and Climate Change, vol. 10, no. 2, pp. 237-242, June 2019.

[12] J. Kim, J. Lee, Y. Song, H. Han, J. Joo, "Modeling the Runoff Reduction Effect of Low Impact Development Installations in an Industrial Area, South Korea,” Water, vol. 10, no. 8, pp. 1-15, July 2018.

[13] N. Chang, J. Lu, T. F. M. Chui, N. Hartshorn, "Global policy analysis of low impact development for stormwater management in urban regions," Land Use Policy, vol. 70, pp. 368-383, January 2018.

[14] F. Kong, Y. Ban, H. Yin, P. James, I. Dronova, "Modeling stormwater management at the city district level in response to changes in land use and low impact development," Environmental Modelling \& Software, vol. 95, pp. 132-142, September 2017.

[15] L. Yao, W. Wei, L. Chen, "How does imperviousness impact the urban rainfall-runoff process under various storm cases?” Ecological Indicators vol. 60, pp. 893-905, January 2016.

[16] M. A. P. Mercado, B. Y. Lee, S. A. Memon, S. R. Umer, I. Salim, "Influence of land development on stormwater runoff from mixed land use and land cover catchment," Science of the Total Environment, vol. 599-600, pp. 2142-2155, December 2017.

[17] R. I. Siregar, Eds., IOP Conference Series: Earth and Environmental Science, October 11, 2017, Medan, Indonesia, IOP Publishing, 2018.

[18] H. Tamiami, F. Khaira, A. Fachrudin., IOP Conference Series: Material Science and Engineering, Medan, Indonesia, IOP Publishing, 2018

[19] Z. Xu, L. Xiong, H. Li, J. Xu, X. Cai, K. Chen, J. Wu, "Runoff simulation of two typical urban green land types with the Stormwater Management Model (SWMM): sensitivity analysis and calibration of runoff parameters," Environmental Monitoring and Assessment, vol. 191, no. 343, June 2019.

[20] V. A. Rangari, S. S. Prashanth, N. V. Umamahesh and A. K. Patel, "Simulation of Urban Drainage System Using a Storm Water Management Model (SWMM),” Asian Journal of Engineering and Applied Technology, vol. 7, no. S1, pp. 7-10, April 2018. 
[21] A. G. Limos, K. J. B. Mallari, J. Baek, H. Kim, S. Hong, J. Yoon, “Assessing the significance of evapotranspiration in green roof modelling by SWMM," Journal of Hydroinformatics, vol. 20, no. 3, May 2018.

[22] F. Liwanag, D. S. Mostrales, M. T. T. Ignacio, J. Orejudos, "Flood Modeling Using GIS and PCSWMM," Engineering Journal, vol. 22, no. 3, June 2018.

[23] S. Hossain, G. A. Hewa, S. W. Hewage, "A Comparison of Continuous and Event-Based Rainfall-Runoff (RR) Modelling Using EPA-SWMM,” Water, vol. 11, March 2019.

[24] C. G. Song, E. S. Chung, K. Won, "Use of the Minimax Regret Approach for Robust Selection of Rainfall-Runoff Model Parameter Values Considering Multiple Events and Multiple Performance Indices,” KSCE Journal of Civil Engineering, vol. 22, no. 4, pp 1515-1522, April 2018.

[25] I. Yucel, A. Onen, K. K. Yilmaz, D. J. Gochis, "Calibration and evaluation of a flood forecasting system: utility of numerical weather prediction model, data assimilation and satellite-based rainfall,” Journal of Hydrology, vol. 523, pp. 49-66, April 2015. 